\title{
Title: Molecular characterization of effector protein SAP54 in Bellis Virescence
} Phytoplasma (16SrIII-J)

\author{
Authors: Franco D Fernánde $z^{1,{ }^{*}}$, Humberto J Debat $^{1}$ and Luis R Conci ${ }^{1}$
}

1. Instituto de Patología Vegetal (IPAVE), CIAP-INTA. Camino 60 cuadras km 5 1/2 (X5020ICA), Córdoba. Argentina

*Corresponding autor: Dr. Franco D Fernández, e-mail: fernandez.franco@inta.gob.ar

\begin{abstract}
Phytoplasmas are wall-less bacteria, with a parasitic life style responsible for numerous plant diseases worldwide. The genomic landscape of phytoplasmas has been scarcely studied. Nevertheless, since the introduction of next generation sequencing technologies, genome wide studies of these pathogens are flourishing and a handful of phytoplasmas genomes are available in public databases. In South America, phytoplasmas from 16Srlll group (X-disease) are the most widely distributed, and only a draft genome from a phytoplasmas $16 \mathrm{Srlll}-\mathrm{J}$ infected periwinkle from Chile has been generated (Phytoplasma Vc33). Here, in grafting experiments we characterized the phenotypic signatures of an Argentinian daisy derived isolate of a $16 \mathrm{Srlll}-\mathrm{J}$ phytoplasma (Bellis Virescence Phytoplasma) infecting periwinkle. Moreover, we applied a pipeline for genome wide annotation of the $V_{c} 33$ genome and identified the effector protein SAP54. We then employed the obtained data to amplify, clone, sequence and characterize a SAP54 orthologue protein of Bellis Virescence Phytoplasma. Structural and phylogenetic analyses suggested that the identified SAP54 is highly conserved, and that its co-divergence among phytoplasma is not directly consistent with the evolutionary trajectories derived from rRNA analyses. The results gathered here could provide the basis for reverse genetics experiments using 16Srlll-J SAP54 proteins to assess their eventual influence in pathogenesis.
\end{abstract}




\section{Introduction}

Phytoplasmas are wall-less bacteria, with parasitic life style responsible for numerous plant diseases worldwide (Hogenhout et al. 2008; Lee et al. 2000; Maejima et al. 2014a). More than 1,000 plant species have been reported to be affected by these pathogens including crops, ornamental plants and trees (Bertaccini et al. 2014). Phytoplasmas are obligate parasites of plant phloem and of insect vectors. Within plants they have a habitat restricted to the sieve elements of the phloem where they grow and multiply (Christensen et al. 2004). Despite numerous efforts, it has been challenging to obtain stable in vitro phytoplasma cultures (Zhao et al. 2015), which limited the study of this kind of pathogen. Hence, basic forward or reverse genetics strategies to characterize their gene repertoire have been unattainable. In this scenario, most studies dealing with phytoplasmas have relied in genomic annotation approaches to infer and understand basic aspects of pathogenicity of these bacteria. While five genomes of phytoplasmas have been reported based on traditional Sanger technologies (Oshima et al. 2004; Bai et al. 2006; Tran-Nguyen et al. 2008, Kube et al. 2008, Andersen et al. 2013), since the implementation of next generation sequencing (NGS) methods, a rapid increase of available genome data has scaled. Since NGS, one additional complete genome has been depicted (Orlovskis et al. 2017), and other 16 have been partially (draft) sequenced (Chung et al. 2013; Mitrović et al. 2014; Saccardo et al. 2012, Fischer et al. 2016; Pacifico et al. 2015; Zamorano and Fiore 2016; Sparks et al. 2018). Analyzes of these genomes have shown, despite their small size, the phytoplasma genome contains a substantial number of genes in multiple copies (Bai et al. 2006; Davis et al. 2003; Jomantiene and Davis 2006; Oshima et al. 2004). Most of these genes are organized in clusters dubbed potential mobile units (PMUs) (Bai et al. 2006) or sequence-variable mosaics (SVMs) (Jomantiene et al. 2007; Oshima et al. 2004). In these regions, genes have been identified for membranebound proteins and most of the effector protein genes, both associated with virulence factors (Hogenhout and Bos 2011; Toruño et al. 2010).

It has been hypothesized that effector proteins of phytoplasmas induce morphological and physiological changes in host plants, which could increase pathogen fitness during infection (Sugio et al. 2011). For instance, these phytoplasmas secreted proteins could produce phyllody, a symptoms that causes conversion of floral organs into green leaf-like organs, which may prolong the life span of their hosts, since as biotrophic pathogens phytoplasmas require a host to live (Sugio et al. 2011). Recently, it was shown that a family of highly conserved phytoplasma virulence factors, designated as a phyllody-inducing gene family (Phyllogen, SAP54 homologues), 
induce phyllody and other floral malformations in Arabidopsis thaliana (MacLean et al. 2011; Maejima, et al. 2014b; Yang et al. 2015). In addition, a recent report has shown that Phyllogen can induce phyllody in several species of angiosperms (Kitazawa et al. 2017), so these proteins have been proposed to play a central role as key factors involved in the generalized virulence of phytoplasmas.

In South America phytoplasmas from 16Srlll group (X-disease) are the most widely distributed and with the broader host range. Within this group, phytoplasmas belonging to subgroup 16Srlll-J were associated to diverse diseases in Argentina, Chile and Brazil (Fernández et al. 2017; Fugita et al. 2017; Montano et al. 2011). Plant species affected by this subgroup are diverse and include garlic (Allium sativum), chayote (Sechium edule), sunflower (Helianthus annuus), cauliflower (Brassica oleracea), eggplant (Solanum melongena), strawberry (Fragaria $\times$ ananassa), daisy (Bellis perennis), woolflowers (Celosia spp.), periwinkle (Catharanthus roseus), parrot fruit (Aegiphila verticillata), ironweed (Vernonia brasiliana), lettuce (Lactuca sativa), Swiss chard (Beta vulgaris) and cassava (Manihot esculenta) (Montano et al. 2011; Pérez-López et al. 2016; Quiroga et al. 2017; Fernández et al. 2018). Despite the growing importance of this particular subgroup of phytoplasmas, only one draft genome has been obtained so far (Zamorano and Fiore 2016). Moreover, there are no reports describing effector proteins in phytoplasmas from subgroup $16 \mathrm{Srlll}-\mathrm{J}$ present in Argentina. In the present work, we used the available genomic information in order to detect and characterize for the first time the SAP54 protein sequence in a phytoplasma isolate of subgroup 16Srlll-J in Argentina.

\section{Materials and methods}

\subsection{Plant material, graft transmission and symptomatology evaluation}

Bellis virescence Phytoplasma (BellVir) is a phytoplasma belonging to subgroup 16Srlll-J previously described in association to virescence and phyllody on daisy (Bellis perennis) (Galdeano et al., 2013). This phytoplasma was maintained and propagated in periwinkle (Catharathus roseus) from daisy (Bellis perennis) infected plants by grafting. In this work we used BellVir phytoplasma as representative strain of subgroup 16Srlll-J. In order to evaluate the symptomatology developed by BellVir infection, 10 periwinkle plants ( 5 of white flowers, 5 of pink flowers) (2-3 months old) agamically obtained by rooting cuttings, were grafted with this phytoplasma. The periwinkle plants came from two mother plants (1 white flower, 1 pink flower) so they constituted an isogenic line. The grafted plants were maintained in humid chambers for 15 days. After this period, the plants were kept under controlled conditions of 
temperature $\left(25^{\circ} \mathrm{C}\right)$ and humidity ( $\mathrm{RH}$ 60-80\%) in greenhouses. Evolution of symptomatology was evaluated by visual inspection, focusing attention on phyllody and virescence symptoms. Phytoplasmas detection was evaluated by PCR using the Xdisease group (16SrIII) specific primers P1/Xint (Smart et al. 1996), which amplify a fragment $\sim 1.6 \mathrm{~kb}$ of $16 \mathrm{~S}$ rRNA operon. DNA used as template was isolated from petioles and midribs of grafted periwinkles (symptomatics, 3-5 months after graft) and healthy periwinkles were ground in liquid nitrogen and DNA purified according to Doyle \& Doyle (1990). PCR reactions were performed in solutions containing $100 \mathrm{ng}$ of DNA, $0.4 \mathrm{mM}$ of each primer, $200 \mathrm{mM}$ of each dNTP, $1 \mathrm{U}$ of GoTaq ${ }^{\circledR}$ DNA polymerase, $1 \mathrm{X}$ polymerase buffer (Promega, USA) and sterile water to a final volume of $40 \mu \mathrm{l}$. PCR amplifications were evaluated trough electrophoresis in agarose gel stained with GeIRed® (Biotium, USA).

\subsection{Detection and characterization of effector protein SAP54 homolog in 16Srlll-J reference genome}

So far, only one draft genome has been described for the subgroup 16Srlll-J (Zamorano and Fiore, 2016). The complete sequences (29 contigs) were retrieved from Genbank (accession number: LLKK00000000.1, Bioproject PRJNA293833) and CDSs were annotated using the Rapid Annotation using Subsystem Technology (RAST) server (http://rast.nmpdr.org). Among the total predicted proteins, those with presence of signal peptide (predicted using Signal IP 4.1 as implemented in http://www.cbs.dtu.dk/services/SignalP/ using the sensitive D-cutoff values) and without transmembrane domains outside the signal peptide (predicted with the TMHMM Server v. 2.0 available at http://www.cbs.dtu.dk/services/TMHMM/) were identified. Proteins which passed this filter, and thus considered as putative secreted proteins, were analyzed in order to identify SVM (Sequence-variable mosaic) protein signals (Pfam id: 12113) using the Conserved Domains Database search tool (www.ncbi.nlm.nih.gov/Structure/cdd/wrpsb.cgi, expect value $=0.01$, CDD v3.16 database). Also, a BLASTp search targeting proteins with SVM-signal (consensus sequence: MFKLKNQLLIINIFLFIFLGLFLITNNNQVMAM, E-value $\leq 1 \mathrm{e}-05$ ) against a local dataset (encompassing all the CDSs annotated by RAST) was performed in Geneious R.10 (Biomatters, USA). The final set of proteins (Signal Peptide (+); Transmebrana domains outside SP (-) and SVM-signal (+)) were analyzed by reciprocal BLASTp searches (E-value $\leq 1 \mathrm{e}-05$ ) against Aster yellows witches'-broom phytoplasma AYWB proteins (taxid:322098) for identification of SAPs homologs (Bai et al. 2006). 


\subsection{PCR Amplification and sequencing of the predicted SAP54 gene from BellVir (16SrIII-J) phytoplasma}

Amplification of DNA sequence of BellVir SAP54-LIKE gene was acceded by conventional PCR. A DNA contig harboring a SAP54-LIKE gene was identified and de novo primer design was made using Primer 3 (http://primer3.ut.ee/). PCR reactions were made using DNA from phytoplasma positive and healthy periwinkle plants as a template as previously described in 2.1 (conditions of amplification are described in Supplementary materials). PCR amplification products were purified using GFXcolumns (GE Healthcare, USA) and cloned in pGEM-T easy system (Promega, USA) according to manufacturer. The cloned fragments were bi-directionally Sanger sequenced (Macrogen, Korea). A final consensus sequence (3X coverage) was assembled using Geneiuos R.10 software and deposited in Genbank database (NCBI accession number MH756633).

\subsection{Molecular characterization of SAP54-LIKE gene in BellVir phytoplasma}

Consensus sequence of SAP54-LIKE gene was analyzed using Geneious R.10. The SAP54 homologous protein sequence was obtained and structural analysis was conducted as previously described in 2.2 (signal peptide, Transmembrane domains, SVM-signal). BLASTp (nr-database) analysis was performed in order to identify putative SAP54-homologues in NCBI database. Also, phylogenetic relationships were inferred using the SAP54 reference sequences (protein) and 16S rDNA corresponding sequence. Multiple alignments were conducted employing MAFFT (L-INS-i algorithm, BLOSUM62 scoring matrix) and MUSCLE (clustering method: UPGMB, max interations: 8) for SAP54 and 16rDNA sequences respectively. Phylogenetic threes were constructed using the Maximum-Likelihood method (JTT model; gamma distributed, NNI heuristic method) in MEGA6 software (Tamura et al. 2013).

\section{Results and Discussion}

\subsection{BellVir phytoplasma infection in periwinkle}

After 3 months post-graft, plants began to show the first symptoms of virescence. In both white flowers and pink flowers, this symptom was characterized by the presence of flowers with green spots (Figure 1.b, e). After the appearance of this symptom the plants began to develop the characteristic phyllody symptom (Figure 1.c, f). The symptomatology of filodia remained constant until the plants ceased the production of flowers and began to show additional symptoms of chlorosis, shortening of internodes and decrease in leaf size. Total grafted plants (10/10) presented the 
described symptomatology, and by PCR the presence of phytoplasmas was verified in all the plants as well. No amplification was observed in healthy control plant (Figure 1.a, d).

\subsection{Identification of SAP54 homologue in 16Srlll-J phytoplasma genome}

During the annotation process of the draft genome of the periwinkle associated 16Srlll-J phytoplasma, Zamorano and Fiore (2016) detected 11 CDSs containing the SEC translocase complex signal peptide, but the authors stated that they did not find any evidence of SAP11, SAP54, PHYL, or TENGU like genes. As these genes and their products appear to be fundamentals in the pathogenic process of phytoplasma infection, we embarked in an exhaustive exploration of their sequence dataset in order to assess the presence of signatures associated with these important genes. Using the RAST platform a total of 634 CDSs and 30 RNAs sequences were identified in the 16Srlll-J phytoplasma draft genome (Table S1, Supplementary material). The predicted protein sequences of these 634 CDSs were analyzed by Signal IP (gram +, sensitive) and peptide signal was detected in 54 sequences. Putative Secreted Proteins ( $P S P=$ no transmembrane domains after signal-peptide) were identified in 37 out 54 SP-proteins. SVM-signal was identified by CDD search (NCBI) or by sequence homology (BLASTpsearch against local database) in seven CDSs (Table 1). Identification of putative SAP homologues proteins was acceded by BLASTp analysis of these seven putative effector proteins against the Aster Yellows Witches Broom phytoplasma reference genome (NC_007716.1) (Bai et al. 2006). All in all, our pipeline succeeded in the identification, with high confidence, of a putative SAP54 (AYWB_224) homologue (protein ID: fig|33926.32.peg.561, Table 2) in the 16Srlll-J genome. The encoded protein had 114 aa in length $(13.410 \mathrm{kDa})$ and showed a $56 \%$ aa identity (E-value: 3,00 e-24, coverage $85 \%$ ) with the SAP54 reference sequence (Table 2, ABC65341.1).

\subsection{Sequencing and analysis of SAP54 gen of BellVir phytoplasma}

Once the sequence of the putative SAP54 protein in the $16 \mathrm{Srlll}-\mathrm{J}$ reference genome was predicted, primers were designed for the amplification by PCR to confirm our in silico findings. A new set of primers (SAP54Fw1/SAP54Rv1) (Supplementary material) was designed in order to amplify a fragment of $\sim 615 \mathrm{bp}$ containing the putative SAP54 gene (Figure 2.a). Using these primers, products of $\sim 615$ bp were visualized in gel electrophoresis of PCR amplifications with DNA from all periwinkle plants (10/10) infected with Bel/Vir phytoplasma, and no PCR products were evident in DNA obtained from uninfected periwinkle plants. Amplifications products from two infected plants were bi-directionally Sanger sequenced and compared sharing a $100 \%$ 
identity. A final consensus sequence was deposited in Genbank with MH756633 accession number. The assembled sequence (615 bp) contains a single ORF (+1frame, position 41-394) of 354 nt which encodes a protein of 117 aa. The sequenced Bel/Vir protein shared an $83.3 \%$ aa identity with the 114 aa SAP54 protein predicted in the draft genome of periwinkle associated 16Srlll-J phytoplasma (Zamorano and Fiore 2016). This protein presented a signal peptide (SP, position 3233) and no transmembrane domain after the SP. The SVM-signal (pfam12113) was also confirmed (e-value $=5.89 \mathrm{e}-06)$ from position 1 to 33 (MFRSKNQFKIIHLCLIAFIGLLFIFNNHQLMAM). A comparison with the SAP54 reference sequence $(A Y W B)$ showed an aa identity value of $51 \%$ and a conservation of the typical SAP54 structure (Figure 2.a-b). A multiple alignment using SAP54 homologues available from genbank, showed a consistent deletion of six aa (position 47-52) in BellVir, Vc33 phytoplasma (both from subgroup 16SrllI-J) and also from 'Ca. Phytoplasma solani' (subgroup 16SrXII-B). In addition, these three SAP54 homologues presented at the C-region a three aa insertion with a conserved $\mathrm{NN}(\mathrm{I} / \mathrm{L})$ motif (Figure 2.b). These sequences (Vc33 and 'Ca. Phytoplasma solani') were also the most similar in terms of identity (Table 3). The C-terminal end (residues 106 to 129) was the most conserved throughout all the compared sequences. Interestingly, this region is significantly associated with coiled-coils structural motifs (Figure 2.a-b).

Phylogenetic analyses were conducted from both SAP54 protein sequences and 16S rDNA sequences (Figures 2.c-d). The 16S rDNA is the most widely used gene for evaluation of phylogenetic relationships and taxonomic assignment in phytoplasmas (Lee et al., 1998; 2000). For SAP54 protein sequences, a maximum likelihood tree showed that BellVir and Vc33 were grouped in the same clade with the ' $\mathrm{Ca}$. Phytoplasma solani' (Figure 2.d). Interestingly, the general topology of this tree does not consistently correspond to that of the $16 \mathrm{~S}$ gene, since the groupings generated do not share the same clustered taxonomic groups (Figure 2.d). Given the intrinsic nature of this virulent associated proteins and their influence in the pathogenic outcome of plant-pathogen interactions, it is tempting to suggest that the inconsistences in the evolutionary clustering of rRNA and SAP54 trees might be associated with selective pressure and active genomic drift of these specific proteins. Further studies, in the context of additional data, should assess genome based analyses of evolutionary trajectories of these pathogens. 


\section{Conclusions}

In this work we demonstrated by grafting tests on periwinkle plants, that infection by BellVir (16Srlll-J) phytoplasma causes severe symptoms of virescence and phyllody. Previous studied suggest that such symptomatology could be triggered by a phyllody-inducing gene family (Phyllogen, SAP54 effector protein) (MacLean et al. 2011; Maejimaet al. 2014; Yang et al. 2015) in several species of angiosperms (Kitazawa et al. 2017). Among the diversity of phytoplasmas composing the 16Srlll-J clade, some strains have been also reported to induce virescence-phyllody symptoms in sunflower (Guzmán et al. 2014), squash (Galdeano et al. 2013) and in periwinkle (Pérez-López et al. 2016). These outcomes could be explained by the presence of SAP54 homologues proteins or alternative pathways. However, experimental data to confirm this hypothesis remains elusive. Zamorano and Fiore (2016) generated the first draft genome of a phytoplasma from subgroup 16Srlll-J. An exhaustive exploration of their sequence dataset allowed us to identify with high confidence a putative SAP54 (AYWB_224) homologue. We then employed this data to amplify, clone, sequence and characterize a SAP54 orthologous protein of Bellis Virescence Phytoplasma. The sequenced BellVir SAP54 protein (MH756633) conserved the typical structure of SAP54 (phyllogen) reference protein (Figure 2.b). The BellVir SAP54 protein (117aa$13.69 \mathrm{kDa}$ ) shared an $83.3 \%$ aa identity with the predicted SAP54 of Vc33 draft genome and $51 \%$ with the SAP54 reference sequence (ABC65341). Comparative analyses between SAP54 homologues showed that the C-terminal end is the most highly conserved region throughout all the assessed sequences. Interestingly, this region is significantly associated with coiled-coils structural motifs, which could provide new clues about the mechanisms of action of this effector. Phylogenetic analyses suggested that the identified SAP54 is highly conserved, and that its co-divergence among phytoplasma is not directly consistent with the evolutionary history derived from rRNA analyses. In the present work, the identification and molecular characterization of a SAP54 protein homologous in a phytoplasma belonging to subgroup $16 \mathrm{Srlll}-\mathrm{J}$ was performed for the first time. The information generated here will be instrumental for further investigation of the eventual mechanisms of pathogenicity associated with this effector and thereby contribute to the overall knowledge of the pathosystem. 


\section{Funding information}

This work was supported by INTA (PNPV. PE1. 1135022; PE3. 1135024) and FONCyT PICT2016-0862.

\section{Conflicts of interest}

The authors declare that there is no conflict of interest, and no humans or animals were subjects in this work.

\section{References}

Andersen, M. T., Liefting, L. W., Havukkala, I., \& Beever, R. E. (2013). Comparison of the complete genome sequence of two closely related isolates of "Candidatus Phytoplasma australiense" reveals genome plasticity. BMC Genomics, 14(1), 1. doi:10.1186/1471-2164-14-529

Bai, X., Zhang, J., Ewing, A., Miller, S. A., Radek, A. J., Shevchenko, D. V., et al. (2006). Living with genome instability: The adaptation of phytoplasmas to diverse environments of their insect and plant hosts. Journal of Bacteriology, 188(10), 3682-3696. doi:10.1128/JB.188.10.3682-3696.2006

Bertaccini, A., Duduk, B., Paltrinieri, S., \& Contaldo, N. (2014). Phytoplasmas and Phytoplasma Diseases: A Severe Threat to Agriculture. American Journal of Plant Sciences, 05(12), 1763-1788. doi:10.4236/ajps.2014.512191

Chang, S.-H., Cho, S.-T., Chen, C.-L., Yang, J.-Y., \& Kuo, C.-H. (2015). Draft Genome Sequence of a 16Srll-A Subgroup Phytoplasma Associated with Purple Coneflower (Echinacea purpurea) Witches' Broom Disease in Taiwan. Genome Announcements, 3(6), e01398-15. doi:10.1128/genomeA.01398-15

Christensen, N. M., Nicolaisen, M., Hansen, M., \& Schulz, A. (2004). Distribution of Phytoplasmas in Infected Plants as Revealed by Real-Time PCR and Bioimaging. Molecular Plant-Microbe Interactions, 17(11), 1175-1184. doi:10.1094/MPMI.2004.17.11.1175

Chung, W. C., Chen, L. L., Lo, W. S., Lin, C. P., \& Kuo, C. H. (2013). Comparative Analysis of the Peanut Witches'-Broom Phytoplasma Genome Reveals Horizontal Transfer of Potential Mobile Units and Effectors. PLOS ONE, 8(4), 1-10. doi:10.1371/journal.pone.0062770

Davis, R. E., Jomantiene, R., Kalvelyte, A., \& Dally, E. L. (2003). Differential amplification of sequence heterogeneous ribosomal RNA genes and classification of the "Fragaria multicipita" phytoplasma. Microbiological Research, 158(3), 229- 
236. doi:10.1078/0944-5013-00201

Doyle, JJ; Doyle, J. (1990). Doyle\&Doyle_Focus_1990_CTAB.pdf.

Fernández, F. D., Meneguzzi, N. G., \& Conci, L. R. (2017). Identification of three novel subgroups within the $\mathrm{X}$-disease group phytoplasma associated with strawberry redness disease. International Journal of Systematic and Evolutionary Microbiology, 67(3), 753-758. doi:10.1099/ijsem.0.001636

Fernández, F., Uset, A., Baumgratz, G., \& Conci, L. (2018). Detection and identification of a 16 Srlll-J phytoplasma affecting cassava ( Manihot esculenta Crantz ) in Argentina, 1-5.

Fischer, A., Santana-Cruz, I., Wambua, L., Olds, C., Midega, C., Dickinson, M., et al. (2016). Draft Genome Sequence of “Candidatus Phytoplasma oryzae" Strain Mbita1, the Causative Agent of Napier Grass Stunt Disease in Kenya. Genome Announcements, 4(2), e00297-16. doi:10.1128/genomeA.00297-16

Fugita, J. M. S., Pereira, T. B. C., Banzato, T. C., Kitajima, E. W., Souto, E. R., \& Bedendo, I. P. (2017). Occurrence of a subgroup 16Srlll-J phytoplasma in nonsymptomatic Brachiaria decumbens cultivated in a grazing area. Tropical Plant Pathology, 42(6), 500-503. doi:10.1007/s40858-017-0174-0

Galdeano, E., Guzmán, F. A., Fernández, F., \& Conci, L. R. (2013). Genetic diversity of $16 \mathrm{Srlll}$ group phytoplasmas in Argentina. Predominance of subgroups 16Srlll-J and $B$ and two new subgroups 16 SrlII-W and X. European Journal of Plant Pathology, 137(4), 753-764. doi:10.1007/s10658-013-0285-5

Guzmán, F. A., Giolitti, F., Fernández, F., Nome, C., Lenardon, S., \& Conci, L. (2014). Identification and molecular characterization of a phytoplasma associated with sunflower in Argentina. European Journal of Plant Pathology, 138(4), 679-683. doi:10.1007/s10658-013-0352-y

Hogenhout, S. A., \& Bos, J. I. B. (2011). Effector proteins that modulate plant-insect interactions. Current Opinion in Plant Biology, 14(4), 422-428.

doi:10.1016/j.pbi.2011.05.003

Hogenhout, S. A., Oshima, K., Ammar, E. D., Kakizawa, S., Kingdom, H. N., \& Namba, S. (2008). Phytoplasmas: Bacteria that manipulate plants and insects. Molecular Plant Pathology, 9(4), 403-423. doi:10.1111/j.1364-3703.2008.00472.x 
Jomantiene, R., \& Davis, R. E. (2006). Clusters of diverse genes existing as multiple, sequence-variable mosaics in a phytoplasma genome. FEMS Microbiology Letters, 255(1), 59-65. doi:10.1111/j.1574-6968.2005.00057.x

Jomantiene, R., Zhao, Y., \& Davis, R. E. (2007). Sequence-Variable Mosaics: Composites of Recurrent Transposition Characterizing the Genomes of Phylogenetically Diverse Phytoplasmas. DNA and Cell Biology, 26(8), 557-564. doi:10.1089/dna.2007.0610

Kakizawa S, Makino A, Ishii Y, Tamaki H, K. Y. (2014). Draft Genome Sequence of “ Candidatus Phytoplasma asteris "Strain. Genome Announcements, 2(5), 9-10. doi:10.1128/genomeA.00944-14.Copyright

Kitazawa, Y., Iwabuchi, N., Himeno, M., Sasano, M., Koinuma, H., Nijo, T., et al. (2017). Phytoplasma-conserved phyllogen proteins induce phyllody across the Plantae by degrading floral MADS domain proteins. Journal of Experimental Botany, 68(11), 2799-2811. doi:10.1093/jxb/erx158

Kube, M., Schneider, B., Kuhl, H., Dandekar, T., Heitmann, K., Migdoll, A. M., et al. (2008). The linear chromosome of the plant-pathogenic mycoplasma "Candidatus Phytoplasma mali." BMC Genomics, 9, 1-14. doi:10.1186/1471-2164-9-306

Lee, I.-M., Davis, R. E., \& Gundersen-Rindal, D. E. (2000). P HYTOPLASMA $\square$ : Phytopathogenic Mollicutes. Annual Review of Microbiology, 54, 221-255. doi:doi:10.1146/annurev.micro.54.1.221

MacLean, A. M., Sugio, A., Makarova, O. V., Findlay, K. C., Grieve, V. M., Toth, R., et al. (2011). Phytoplasma Effector SAP54 Induces Indeterminate Leaf-Like Flower Development in Arabidopsis Plants. Plant Physiology, 157(2), 831-841. doi:10.1104/pp.111.181586

Maejima, K., Iwai, R., Himeno, M., Komatsu, K., Kitazawa, Y., Fujita, N., et al. (2014). Recognition of floral homeotic MADS domain transcription factors by a phytoplasmal effector, phyllogen, induces phyllody. Plant Journal, 78(4), 541-554. doi:10.1111/tpj.12495

Maejima, K., Oshima, K., \& Namba, S. (2014). Exploring the phytoplasmas, plant pathogenic bacteria. Journal of General Plant Pathology, 80(3), 210-221. doi:10.1007/s10327-014-0512-8

Mitrović, J., Siewert, C., Duduk, B., Hecht, J., Mölling, K., Broecker, F., et al. (2014). 
Generation and analysis of draft sequences of "stolbur" phytoplasma from multiple displacement amplification templates. Journal of Molecular Microbiology and Biotechnology, 24(1), 1-11. doi:10.1159/000353904

Montano, H. G., Cunha, J. O., \& Pimentel, J. P. (2011). Phytoplasmas in Brazil: An update. Bulletin of Insectology, 64(SUPPL. 1), 251-252.

Orlovskis, Z., Canale, M. C., Haryono, M., Lopes, J. R. S., Kuo, C. H., \& Hogenhout, S. A. (2017). A few sequence polymorphisms among isolates of Maize bushy stunt phytoplasma associate with organ proliferation symptoms of infected maize plants. Annals of Botany, 119(5), 869-884. doi:10.1093/aob/mcw213

Oshima, K., Kakizawa, S., Nishigawa, H., Jung, H. Y., Wei, W., Suzuki, S., et al. (2004). Reductive evolution suggested from the complete genome sequence of a plant-pathogenic phytoplasma. Nature Genetics, 36(1), 27-29.

doi:10.1038/ng1277

Pacifico, D., Galetto, L., Rashidi, M., Abbà, S., Palmano, S., Firrao, G., et al. (2015). Decreasing global transcript levels over time suggest that phytoplasma cells enter stationary phase during plant and insect colonization. Applied and Environmental Microbiology, 81(7), 2591-2602. doi:10.1128/AEM.03096-14

Pérez-López, E., Luna-Rodríguez, M., Olivier, C. Y., \& Dumonceaux, T. J. (2016). The underestimated diversity of phytoplasmas in Latin America. International Journal of Systematic and Evolutionary Microbiology, 66(1), 492-513.

doi:10.1099/ijsem.0.000726

Quaglino, F., Kube, M., Jawhari, M., Abou-Jawdah, Y., Siewert, C., Choueiri, E., et al. (2015). "Candidatus Phytoplasma phoenicium" associated with almond witches'broom disease: From draft genome to genetic diversity among strain populations Microbial genetics, genomics and proteomics. BMC Microbiology, 15(1), 1-15. doi:10.1186/s12866-015-0487-4

Quiroga, N., Bustamante, M., Gamboa, C., Molina, J., Zamorano, A., \& Fiore, N. (2017). 16Srlll-J phytoplasmas infecting lettuce and Swiss chard crops in Chile. Phytopathogenic Mollicutes, 7(2), 91. doi:10.5958/2249-4677.2017.00012.3

Saccardo, F., Martini, M., Palmano, S., Ermacora, P., Scortichini, M., Loi, N., \& Firrao, G. (2012). Genome drafts of four phytoplasma strains of the ribosomal group 16SrllI. Microbiology (United Kingdom), 158(11), 2805-2814.

doi:10.1099/mic.0.061432-0 
Smart, C. D., Schneider, B., Blomquist, Ç. L., Guerra, L. J., Harrison, N. A., Ahrens, U., et al. (1996). Phytoplasma-specific PCR primers based on sequences of the 16S23S rRNA spacer region. Applied and Environmental Microbiology, 62(8), 29882993.

Sparks, M. E., Bottner-Parker, K. D., Gundersen-Rindal, D. E., \& Lee, I. M. (2018). Draft genome sequence of the New Jersey aster yellows strain of 'Candidatus Phytoplasma asteris.' PLoS ONE, 13(2), 1-16. doi:10.1371/journal.pone.0192379

Sugio, A., MacLean, A. M., Kingdom, H. N., Grieve, V. M., Manimekalai, R., \& Hogenhout, S. A. (2011). Diverse Targets of Phytoplasma Effectors: From Plant Development to Defense Against Insects. Annual Review of Phytopathology, 49(1), 175-195. doi:10.1146/annurev-phyto-072910-095323

Toruño, T. Y., Seruga Musić, M., Simi, S., Nicolaisen, M., \& Hogenhout, S. A. (2010). Phytoplasma PMU1 exists as linear chromosomal and circular extrachromosomal elements and has enhanced expression in insect vectors compared with plant hosts. Molecular Microbiology, 77(6), 1406-1415. doi:10.1111/j.13652958.2010.07296.x

Tran-Nguyen, L. T. T., Kube, M., Schneider, B., Reinhardt, R., \& Gibb, K. S. (2008). Comparative genome analysis of "Candidatus Phytoplasma australiense" (subgroup tuf-Australia I; rp-A) and "Ca. phytoplasma asteris" strains OY-M and AY-WB. Journal of Bacteriology, 190(11), 3979-3991. doi:10.1128/JB.01301-07

Yang, C.-Y., Huang, Y.-H., Lin, C.-P., Lin, Y.-Y., Hsu, H.-C., Wang, C.-N., et al. (2015). MicroRNA396-Targeted SHORT VEGETATIVE PHASE Is Required to Repress Flowering and Is Related to the Development of Abnormal Flower Symptoms by the Phyllody Symptoms1 Effector. Plant Physiology, 168(4), 1702-1716. doi:10.1104/pp.15.00307

Zamorano, A., \& Fiore, N. (2016). Draft Genome Sequence of 16Srlll-J Phytoplasma, a Plant Pathogenic Bacterium with a Broad Spectrum of Hosts. Genome Announcements, 4(3), e00602-16. doi:10.1128/genomeA.00602-16

Zhao, Y., Davis, R. E., Wei, W., \& Lee, I. M. (2015). Should 'Candidatus Phytoplasma' be retained within the order Acholeplasmatales? International Journal of Systematic and Evolutionary Microbiology, 65(3), 1075-1082. doi:10.1099/ijs.0.000050 
Table 1: Identification Putative secreted proteins (PSP) of Vc33 Phytoplasma (16Srlll-J) CDSs. Protein IDs were assigned by RAST (See supplementary table 1). a: position and e-value of SVM-signal (pfam12113) using the Conserve Domains Database search tool; b: position , identity percentages and e-values of PSP against SVM consensus domain using BLASTp (local database).

\begin{tabular}{|c|c|c|c|c|c|c|c|c|c|c|c|}
\hline \multirow[b]{3}{*}{ Protein ID } & \multirow[b]{3}{*}{ Contig } & \multirow[b]{3}{*}{ Lenght (aa) } & \multirow[b]{3}{*}{ start } & \multirow[b]{3}{*}{ stop } & \multirow[b]{3}{*}{ strand } & \multirow[b]{3}{*}{ SP } & \multicolumn{5}{|c|}{ SVM-signal } \\
\hline & & & & & & & \multicolumn{2}{|c|}{$\mathrm{CDD}^{\mathrm{a}}$} & \multicolumn{3}{|c|}{ BLASTp-SVM $^{0}$} \\
\hline & & & & & & & position & e-value & position & $\%$ id & e-value \\
\hline fig|33926.32.peg.572 & LLKK01000019 & $86(10.207 \mathrm{kDa})$ & 3651 & 3911 & + & $\mathrm{Y}(32-33)$ & $1-33$ & $1,15 \mathrm{E}-04$ & $1-33$ & 60,60 & $2,84 \mathrm{E}-08$ \\
\hline fig|33926.32.peg.331 & LLKK01000007 & $134(15.694$ kDa) & 22314 & 22718 & + & $\mathrm{Y}(32-33)$ & $1-33$ & $3,23 \mathrm{E}-04$ & $1-32$ & 43,80 & $6,87 \mathrm{E}-03$ \\
\hline fig|33926.32.peg.332 & LLKK01000007 & 163 (19.172 kDa) & 22909 & 23472 & + & $Y(32-33)$ & $1-33$ & 4,92E-04 & $1-33$ & 54,50 & $8,80 \mathrm{E}-06$ \\
\hline fig|33926.32.peg.558 & LLKK01000018 & $1108(12.686 \mathrm{kDa})$ & 5457 & 5786 & + & $\mathrm{Y}(31-32)$ & $1-28$ & 2,49E-02 & $1-32$ & 48,50 & $5,65 \mathrm{E}-04$ \\
\hline fig|33926.32.peg.573 & LLKK01000019 & $110(12.927 \mathrm{kDa})$ & 4135 & 4467 & + & $Y(32-33)$ & $1-33$ & 1,13E-01 & $1-33$ & 54,50 & $3,49 \mathrm{E}-07$ \\
\hline fig|33926.32.peg.570 & LLKK01000019 & $361(43.089$ kDa) & 2136 & 3221 & + & $Y(32-33)$ & $1-33$ & 1,72E-01 & $1-33$ & 51,50 & $1,69 \mathrm{E}-05$ \\
\hline fig|33926.32.peg.561 & LLKK01000018 & 114 (13.410 kDa) & 6577 & 6921 & + & $Y(32-33)$ & $1-33$ & 2,83E-01 & $1-33$ & 60,60 & $4,90 \mathrm{E}-07$ \\
\hline
\end{tabular}


Table 2: Identification of SAP (Bai et al., 2006) protein homologues in Putative Secreted Proteins of Vc33 Phytoplasma (16Srlll-J). * BLASTp analysis was conducted in Geneious R.10 software against the genome of AYWB (NC_007716.1) in local database. Putative SAP54 is marked in bold.

\begin{tabular}{|c|c|c|c|c|c|c|}
\hline \multirow[b]{2}{*}{ Protein ID } & \multicolumn{6}{|c|}{ BLASTp-AYWB* } \\
\hline & Identity & Coverage & E-value & Accesion & Product & $\begin{array}{c}\text { Locus_tag=Putative } \\
\text { SAP }\end{array}$ \\
\hline fig|33926.32.peg.572 & $60 \%$ & $83 \%$ & $3,00 \mathrm{E}-24$ & $\underline{\mathrm{ABC} 65485.1}$ & $\begin{array}{l}\text { conserved hypothetical } \\
\text { protein }\end{array}$ & AYWB_368=SAP67 \\
\hline fig|33926.32.peg.331 & $56 \%$ & $98 \%$ & $1,00 \mathrm{E}-44$ & $\underline{\mathrm{ABC} 65149.1}$ & $\begin{array}{l}\text { conserved hypothetical } \\
\text { protein }\end{array}$ & AYWB_032=SAP05 \\
\hline fig|33926.32.peg.332 & $72 \%$ & $99 \%$ & $8,00 E-63$ & $\underline{\mathrm{ABC} 65190.1}$ & $\begin{array}{l}\text { conserved hypothetical } \\
\text { protein }\end{array}$ & AYWB_073=SAP19 \\
\hline fig|33926.32.peg.558 & $59 \%$ & $100 \%$ & $1,00 \mathrm{E}-23$ & $\underline{\mathrm{ABC} 65150.1}$ & $\begin{array}{l}\text { conserved hypothetical } \\
\text { protein }\end{array}$ & AYWB_033=SAP06 \\
\hline fig|33926.32.peg.573 & $44 \%$ & $66 \%$ & $1,20 \mathrm{E}-09$ & $\underline{\mathrm{ABC} 65354.1}$ & $\begin{array}{c}\text { conserved hypothetical } \\
\text { protein }\end{array}$ & AYWB_237=SAP41 \\
\hline fig|33926.32.peg.570 & $58 \%$ & $92 \%$ & $5,00 \mathrm{E}-67$ & $\underline{A B C 65456.1}$ & $\begin{array}{l}\text { conserved hypothetical } \\
\text { protein }\end{array}$ & AYWB_339=SAP49 \\
\hline fig|33926.32.peg.561 & $56 \%$ & $85 \%$ & $3,00 \mathrm{E}-24$ & ABC65341.1 & $\begin{array}{c}\text { conserved hypothetical } \\
\text { protein }\end{array}$ & AYWB_224=SAP54 \\
\hline
\end{tabular}


Table 3: List of sequences used in Phylogenetic analyses. *: aminoacidic identity values against putative SAP54 of BellVir phytoplasma (MH756633).

\begin{tabular}{|c|c|c|c|c|c|}
\hline Candidatus Phytoplasma & Strain & $\begin{array}{c}16 \mathrm{Sr}- \\
\text { subgroup }\end{array}$ & Protein ID & \%id* & Reference \\
\hline Ca. Phytoplasma pruni & Vc33 & 16Srlll-J & LLKK010000018 & 83.33 & Zamorano and Fiore 2016 \\
\hline Ca. Phytoplasma solani & 284-09 & 6SrXII-B & CCP88716 & 71.79 & Mitrovic et al., 2014 \\
\hline Ca. Phytoplasma pruni & JR1 & 16Srlll-A & WP_01791948.1 & 52.85 & Saccardo et al., 2012 \\
\hline Ca. Phytoplasma asteris & OY-M & 16Srl-B & BAD04134 & 48.80 & Oshima et al., 2004 \\
\hline Ca. Phytoplasma asteris & OY-V & 16Srl-B & GAK74327 & 48.80 & Kakizawa et al., 2014 \\
\hline Ca. Phytoplasma asteris & CY-P & 16Srl-B & WP_034172429 & 46.40 & Pacifico et al., 2015 \\
\hline Ca. Phytoplasma asteris & AYWB & rl-A & ABC65341 & 48.00 & Bai et al., 2006 \\
\hline Ca. Phytoplasma trifolii & 16SrVI-A & 16SrVI-A & BAQ08267 & 48.00 & Maejima et al., 2014 \\
\hline - & $\begin{array}{c}\text { PnWB-NTU2011 } \\
\text { EPWB- }\end{array}$ & $\begin{array}{l}16 \text { Srll-A } \\
16 \text { Srll-A }\end{array}$ & EMR14798 & 40.32 & Chung et al., 2013 \\
\hline - & NCHU2014 & $16 \mathrm{SrIX}-\mathrm{B}$ & WP_004994552.1 & 40.32 & Chang et al. 2015 \\
\hline Phoenicium & ChiP & & PQP79243 & 46.40 & Quaglino et al. 2015 \\
\hline
\end{tabular}


bioRxiv preprint doi: https://doi.org/10.1101/411140; this version posted September 11,2018 . The copyright holder for this preprint (which was not certified by peer review) is the author/funder, who has granted bioRxiv a license to display the preprint in perpetuity. It is made available under aCC-BY-NC-ND 4.0 International license.

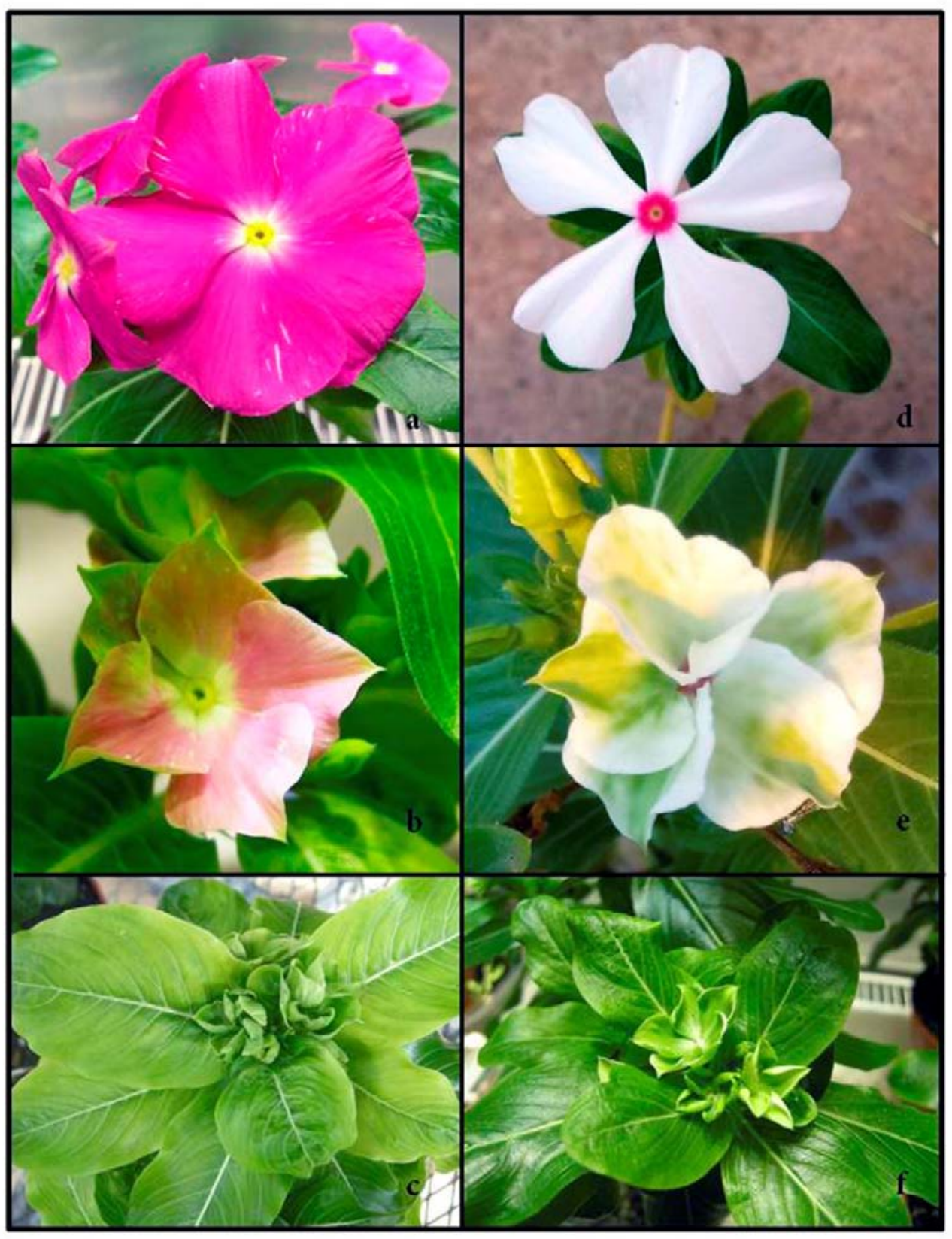

Figure 1: Symptomatology associated to infection of BellVir phytoplasma in grafted periwinkles. 1. a, d: healthy flowers; 1.b,e: symptoms of virescence and 1.c,f : symptoms of phyllody. 
bioRxiv preprint doi: https://doi.org/10.1101/411140; this version posted September 11, 2018. The copyright holder for this preprint (which was not certified by peer review) is the author/funder, who has granted bioRxiv a license to display the preprint in perpetuity. It is made available under aCC-BY-NC-ND 4.0 International license.

a

LLKK01000018 contig LLKK00000000.1 Phytoplasma sp. Vc33

$\begin{gathered}\text { type III DNA-binding } \\ \text { proteins }\end{gathered}$
SAP54-like locus

SAP54 (BellVir)

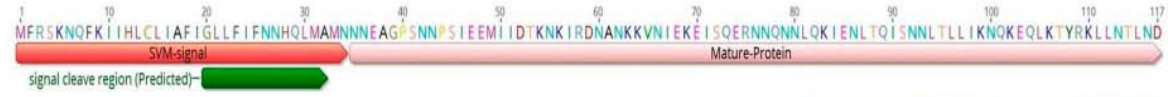

b

Coitd-Coils

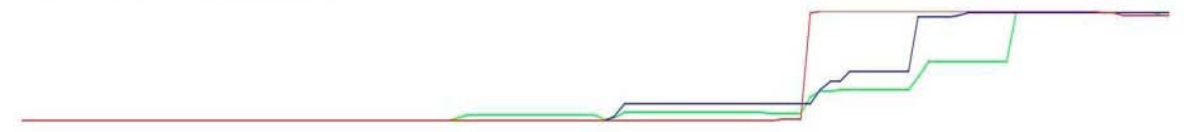

SAP54 (AYWB)

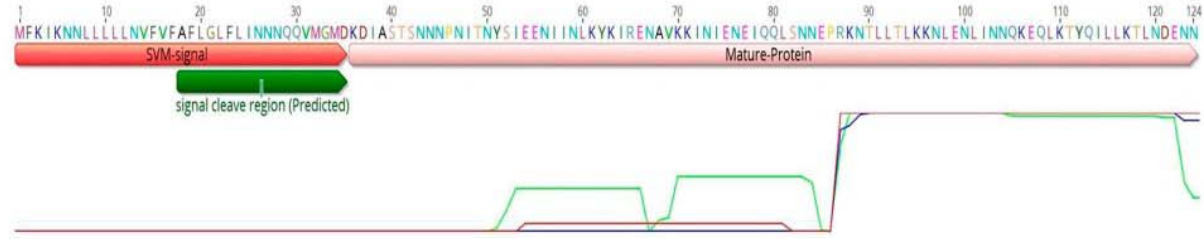

$\mathrm{C}$
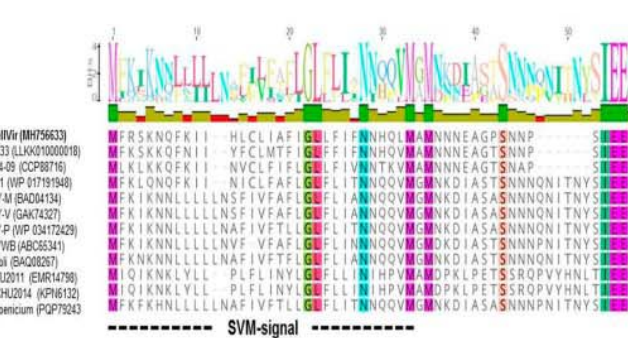

SVM-signal

d
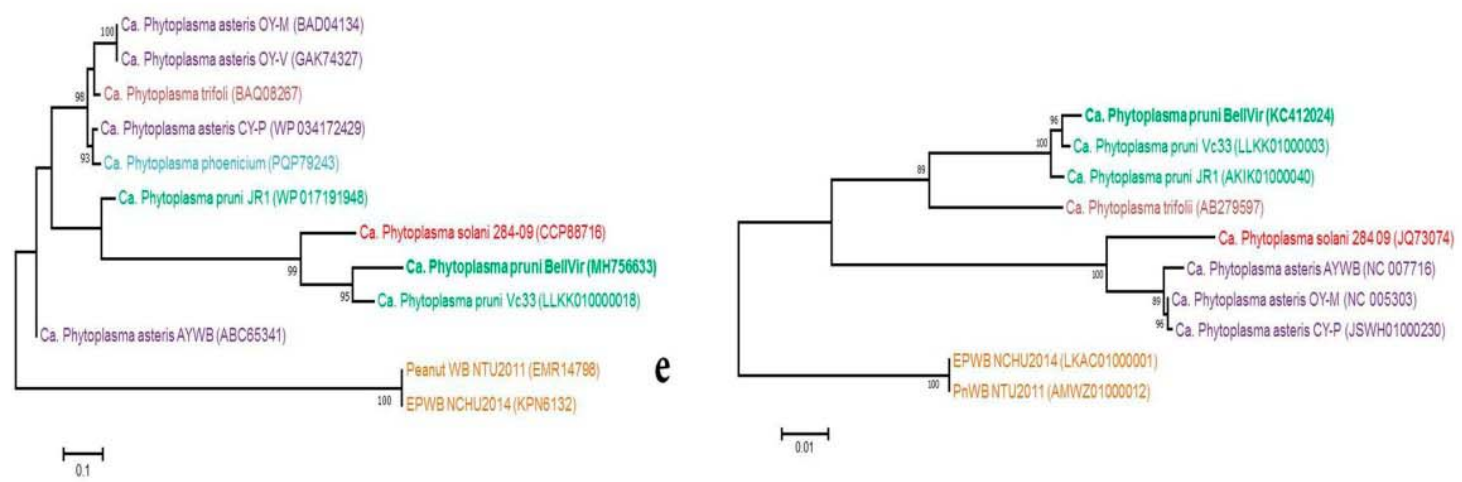
bioRxiv preprint doi: https://doi.org/10.1101/411140; this version posted September 11,2018 . The copyright holder for this preprint (which was not certified by peer review) is the author/funder, who has granted bioRxiv a license to display the preprint in perpetuity. It is made available under aCC-BY-NC-ND 4.0 International license.

Figure 2: Analyses of SAP54 protein sequence of BellVir phytoplasma. a: Genomic context of SAP54 CDS in LLKK01000018 contig, primer binding sites are marked in green. b: comparison of SAP54 structure between BellVir phytoplasma (MH756633) and AYWB phytoplasma (ABC65341); probabilities of coiled-coil regions (MTK matrices) are presented under sequence structure (windows 14-21-28: green, blue and red respectively). c: multiple alignment of SAP54 homologues proteins, identical residues are marked in colors, SVM in dashed line. $\mathbf{d}$ and $\mathbf{e}$ : Phylogenetic trees of SAP54 and 16S rDNA sequences using ML method. The different 'Candidatus Phytoplasma species' are differentiated with colors. The GenBank accession number for each taxon is given in parentheses. The numbers on the branches are bootstrap (confidence) values (1,000 replicates). The scale bar represents the number of amino acid substitutions per site. 
bioRxiv preprint doi: https://doi.org/10.1101/411140; this version posted September 11, 2018. The copyright holder for this preprint (which was not certified by peer review) is the author/funder, who has granted bioRxiv a license to display the preprint in perpetuity. It is made available under aCC-BY-NC-ND 4.0 International license.

Bellvir sequences

>SAP54-LIKE_BellVir_DNA

ATGTTTCGATCAAAАAАCCAАTTTAAАATAАTTCATCTTTGTTTAATCGCTTTTATAGGATTATTATTTA

TTTTTAАTAАTCATCAATTAATGGCGATGAATAATAATGAAGCTGGCCCAAGCAATAATCCATCAATTGA

AGAAATGATTATTGATACAAAAAATAAAATTCGCGATAATGCAAATAAAAAAGTTAATATAGAAAAAGAA

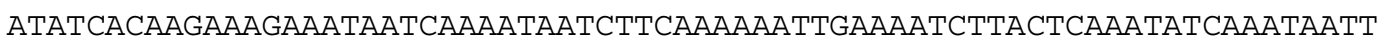

TAАСАTTATTAАTTAAAAATCAAAAAGAACAACTAAAAACCTATAGAAAACTTTTAAATACTTTAAATGA TTAA

>SA54-LIKE_BElIVir_aa

MFRSKNQFKI IHLCLIAFI GLLF I FNNHQLMAMNNNEAGPSNNPS I EEMI IDTKNKIRDNANKKVNIEKE ISQERNNQNNLQKIENLTQISNNLTLLI KNQKEQLKTYRKLLNTLND 